\title{
Foreign Influences in Polish Culinary Taste during the Twentieth Century
}

\author{
Katarzyna J. Cwiertka
}

\section{Introduction}

The political landscape of twentieth-century Poland is highly dynamic. Following the annexation of the Polish territory by Austria, Prussia, and Russia in 1795, the country disappeared from the world's map for over a century, only to reemerge as the Second Polish Republic in 1918. It lasted only for a meager two decades, when it fell victim to the German and Soviet invasions, which resulted, once again, in the loss of independence. The westward advance of the Red Army at the end of the Second World War ultimately led to the establishment of the Polish People's Republic (1947-89), a communist satellite state of the Soviet Union. Finally, the Poles left the twentieth century as citizens of the (Third) Polish Republic, with the brand-new constitution approved in the referendum of 1997.

This political hotchpotch did not leave Polish culinary culture unaffected. In fact, as I will argue in the course of this chapter, the developments of the twentieth century functioned as a catalyst in the formation of what we might call "a Polish taste." The quotation marks are necessary, because the now-taken-for-granted idea that food preferences and styles of eating reflect national identity is not a given, but a modern construct, which is closely linked to the rise of the nation-state and nationalism (Anderson 1991; Palmer 1998). After all, the most salient feature of a national cuisine is bridging regional, ethnic, and class differences that had for centuries differentiated eating habits of the population of the national territory. Tied to the conceptions of national history and cultural heritage, national cuisines tend to acquire a sense of permanence and authenticity, which but rarely are confirmed by historical records (Cwiertka 2006, 2020).

Mainstream depictions of Polish cuisine often take the shape of an inventory of flagship food items considered representative (A Foreigner's Guide to Polish Cuisine 2014). While historians can delineate the origins of those dishes and link them with specific communities, many of them only relatively recently acquired truly national characteristics, meaning that the entire population willingly identifies them as their own. As historian Błażej Brzostek rightfully pointed out, what we nowadays refer to 
as "Polish cuisine" is an amalgamation of four strands of distinct culinary traditions, each representing different social groups that had made up the Polish population until the mid-twentieth century: peasantry and the working class, landed gentry, urban middle class, and different minorities, of which the largest one were the Jews (Brzostek 2010: 17).

In an attempt to define Polish cuisine, culinary historian Jarosław Dumanowski underlined another factor-regional differences - that must be taken into consideration when discussing "Polish" taste in its national dimension. Dumanowski (2019) argues that regional variations are often overlooked in mainstream depictions of Polish food and explains that part of the problem is the damage that half a century of communist rule has inflicted on culinary variety. He lists food shortage, forced resettlement of populations from one region to another, and the propagation of ideologically driven, uniform mass-catering formula among the main reasons behind the decline of local culinary traditions across Poland during the second half of the twentieth century.

Another problem that Dumanowski (2019) identifies in mainstream depictions of Polish food is the image of heavy fare centered on meat. It not only is inaccurate but also detracts importance from the age-old practice of eating freshwater fish and crustaceans. To begin with, the majority of the population simply could not afford large quantities of meat on a daily basis, but even among affluent social classes the habit of regular fish consumption was engrained in the fasting calendar dictated by the Catholic faith (Michalik and Łebkowski 1996: 294). If we were to pinpoint common taste denominators that have the long-standing roots across all social strata and across different regions of what nowadays constitutes a Polish territory, it would most probably be extensive use of fermented vegetables and grains, along with dried mushrooms and smoked foods. Originally applied primarily for its practical application aimed at preservation, smoking and fermenting have in time contributed to a distinctive taste that we might identify as "Polish." For example, a distinctive flavor of Polish sausages derives from the application of smoking in the process of their manufacture.

Foreign influences feature prominently in the depictions of Polish cuisine that can be found in culinary encyclopedias and other publications that explore the history of food and eating on the Polish territory (Kuti 2003; Meller 1994a; Szymanderska 2006: 1-3). This is hardly surprising. After all, most national cuisines are grounded on the combination of long-standing practices characteristic of social groups that have occupied the territory for generations and foreign elements carried more recently by traders, immigrants, and aggressors. Still, the most recent chapter of foreign influence on the culinary culture of contemporary Poland deserves more scrutiny. Assessing its impact is the primary objective of this chapter.

\section{Polish Elites and Foreign Tastes}

Like elsewhere, the culinary culture of Polish elites had for centuries been enriched by foreign imports. The culinary culture of Byzantium possibly reaching the Polish royal court as early as the tenth century is one of the earliest examples, but the most well-known one is the introduction of Mediterranean fruits and vegetables during the 
reign of Princess Bona Sforza of Milan (1494-1557), who became queen of Poland in 1518 (Dembińska 1999: 12-14). The flourishing economy during the following century prompted the diffusion of Italian novelties among the affluent Polish gentry (Meller 1994a: 35-7). In the meantime, the culinary refinement at the royal court continued under the influence of Marie Louise Gonzaga (1611-67), the French wife of King Ladislaus IV Vasa (1595-1649), and his brother John II Casimir Vasa (1609-72). An army of French cooks at the employ of the elite households was critical in disseminating French models on the Polish soil (Czaplicki and Długosz 1976: 120). Their impact was reflected in the introduction of French culinary terms into the Polish language and adaptation of French cooking techniques, such as stuffing, jellying, and glazing into Polish recipes (Meller 1994a: 51). German influences also reached Polish elite, after the electors of Saxony occupied the Polish throne during the first half of the eighteenth century. Since the Saxon elite itself had been influenced by the French culinary fashion, the Germanic impact on Polish haute cuisine through this channel was not particularly significant. However, they are attributed with the introduction of potato, which was to become one of the most important elements of Polish diet.

The sixteenth and seventeenth centuries also left the imprint from across the Eastern border on the Polish culinary culture (Meller 1994a: 39). Turkish, Hungarian, and Armenian dishes entered Poland via trade centers in the cities of Lviv, Vilnius, and Cracow. Armenian merchants were the most important carriers of Middle Eastern spices, nuts, and exotic fruits, which continuously appeared on the tables of the Polish elites. Turkish influences increased due to the Polish-Ottoman Wars (1620-1, 1633-4, $1672-6,1683-99)$ and became particularly pronounced in confectionery and in the preparation of meat dishes (Meller 1994a: 44).

It must be stressed that the developments described here were primarily relevant for the elites, and only reached the middle orders of society to a very limited degree and, if at all, centuries later. This situation began to change from the nineteenth century onward, when a growing number of French, German, and Austrian cookbooks began to circulate throughout the Polish territory, at the time no longer an independent state, but partitioned among its neighbors, the Habsburg Austria, the Kingdom of Prussia, and the Russian Empire. The increased market for printed cookbooks in nineteenthcentury Europe was fostered by several factors, of which an important one was the drop in the prices of books due to the industrialization of paper-making and printing (Eliot and Rose 2007: 579-600). Based on the examinations of the signs of wear found on the copies of the cookbooks that survived in Polish libraries until the present day, material culture historian Beata Meller concludes that they were indeed used in the kitchen (personal communication, August 1996).

Concurrently with the increased circulation of cookbooks written in foreign languages, Polish translations of French and Italian culinary publications became increasingly prominent at the time. The early examples are Kuchnia Polsko-Francuska (the Polish-French Cookery) published in 1810 and Kucharka Doskonala Wiedeńska (the Perfect Viennese Cook) from 1825 (Meller 1994b: 85). These books foreshadowed the first wave of foreign influence in Polish cookery that continued for nearly a century and, in the long run, contributed to the modernization of Polish diet. This transformation took place in the context of the economic and social changes brought 
about by the Industrial Revolution. Although far from spectacular by Western European standards - in 1900, nearly 70 percent of the Polish population lived in the countryside (Zamoyski 1987: 310) —urbanization and the growth of the middle class provided fertile ground for foreign innovation. Ultimately, these factors were crucial in the construction of the blueprint for what Poles today consider "traditional food."

\section{The Reinvention of Home Cooking}

The agents of change that initiated this process were female culinary reformers-Maria Disslowa (1870-1936), Marta Norkowska (1872-1930), Maria Gruszecka (ca 1850post-1913), and Maria Ochorowicz-Monatowa (1866-1925) - who strove to provide the urban middle classes with practical solutions to their daily dilemmas of feeding their families on a budget. These resourceful ladies disseminated new ideas about cooking and nutrition through popular and professional publications, public lectures, and cooking courses. During the 1930s, the young generation of reformers, such as Zofja Czerny-Biernatowa (?-1965) and Marja Strasburger (1896-1963), even utilized radio broadcasts to communicate their advice to the public. ${ }^{1}$

The uncrowned queen among them is, undoubtedly, Lucyna Ćwierczakiewiczowa (1829-1901), the author of the bestselling cookbook 365 Obiadów za Piec Zlotych (365 Dinners for Five Zloty ${ }^{2}$ ), which was republished twenty-four times between 1860 and 1923. ${ }^{3}$ The book provided menu suggestions for each day of the year, divided per month, taking into consideration the seasonal variation of ingredients, including their prices and availability. It relied heavily on foreign borrowings, at times uncredited, but often indicated in the names of the featured recipes. Four different strategies were employed by the author for this purpose: (1) terms such as "à la mode," "à la maître d'hôtel," and "au gratin" were included, indicating their French origins or, possibly, denoting some kind of refinement; (2) geographical names, usually of a city of the alleged origin of the dish were listed, as is the case with chicken soup Orléans Style (Rosół po orleańsku), Herring Hamburg style (Śledzie po hambursku), or Potatoes Lyon-style (Kartofle "à la lyonnaise"); (3) the dish was assigned a particular "nationality," like French dumplings (Kluski francuskie), Chicken Spanish style (Kurczęta po hiszpańsku), Green beans English style (Fasola zielona po angielsku); and, finally, (4) the least recurred method was to include the original name in a foreign language with a short explanation in Polish, for example "Ox-Tail" soup and "Vol au vent" chicken dish (Ćwierczakiewiczowa 1985: 86, 212).

Along with her bestselling book, Ćwierczakiewiczowa provided culinary advice through her cookery column in the progressive women's magazine Bluszcz (Ivy), with which she collaborated for nearly three decades, since its launching in 1865 (Kalkowski 1985: 8). Here, again, she regularly included foreign recipes, with their origins clearly signaled by the names she gave them: Karlsbad Cherry Cake (Ciasto karlsbadzkie z wiśniami), ${ }^{4}$ Beefsteak Hamburg Style (Befsztyk po hambursku), ${ }^{5}$ French Chops (Zrazy francuskie), ${ }^{6}$ English Layer Cake with Wild Strawberries (Tort poziomkowy angielski), ${ }^{7}$ English Pudding in French Pastry (Budyń angielski w francuskim cieście), and so on. ${ }^{8}$ The same pattern was prevalent in cookbooks by other authors that were published throughout the late nineteenth and the early twentieth century, as well as in 
cookery columns of women's magazines like Dobra Gospodyni (Good Housekeeper)— the cheapest women's magazine on the market ${ }^{9-}$ and the more exclusive Pani Domu (The Lady of the House). In the course of 1938, one year before the outbreak of the Second World War, the readers of the latter were offered quite a geographical variety of foreign recipes to try:

French Omelette with Potatoes and Cheese (Omlet francuski z ziemniakami i serem)

Potato Salad Viennese Style (Sałatka ziemniaczana po wiedeńsku)

Italian Veal Salad (Sałatka włoska z cielęciny)

Swiss Pudding with Ham (Budyń szwajcarski z szynką)

Karlsbad Cookies (Ciastka karlsbadzkie)

Argentinean Dishes: Carbonada, Empanadas, Puchero (Potrawy argentyńskie: carbonada, empanadas, puchero)

Argentinean Dessert "Dulce de Leche" (Legumina argentyńska "Dulce de Leche")

Beans à la Bretonne (Fasolka po bretońsku)

Codfish Hamburg Style (Dorsz po hambursku)

Herrings Greek Style (Merlany po grecku)

Hare Italian Style (Zając po włosku) ${ }^{10}$

While the Argentinian "Dulce de Leche" may still remain largely unknown to most Poles even today, certain foreign recipes that had kept reappearing in Polish cookery columns since the late nineteenth century clearly acquired a permanent position in the home cooking repertoire of Polish urban households. They did not disappear from new cookbooks published after the Second World War, even when the new political climate of the Polish People's Republic (1947-89) deemed refined lifestyle detrimental and foreign influences unwelcome. Rather, their position was strengthened through dissemination beyond urban homes and across the social spectrum. In some publications from the communist era, the references to foreign origins of the featured recipes were removed from their names, but a prevailing trend was to retain them. Let us consider the example of the holy grail of Polish cookery-breaded pork cutlet ( $A$ Foreigner's Guide to Polish Cuisine 2014).

The recipe was introduced for the first time in Ćwierczakiewiczowa's bestseller under the name of Viennese Cutlet (Sznycle Wiedeńskie). Similarly, Marta Norkowska's Najnowsza Kuchnia Wytworna i Gospodarska (The Newest Cookery, Refined and Economical) from 1903 and Uniwersalna Książka Kucharska (Universal Cookery Book) by Marya Ochorowicz-Monatowa from 1912 also clearly label this recipe as a Viennese import and list it, as does Ćwierczakiewiczowa, in the veal section (Ochorowicz-Monatowa 1995: 305; Norkowska 1903: 149; Ćwierczakiewiczowa 1985: 185). In a 1948 cookbook titled Żywienie Rodziny (Feeding the Family), a reference to the foreign origin of the dish is nowhere to be found (Czerny and Strasburger 1948: 177-8), but only five years later, the publication by one of the two authors referred to it again as "Viennese style" (Czerny 1954: 249).

This is by no means an isolated example. Many of the dishes that entered home cookery under foreign inspiration since the nineteenth century onward have, by 
the second half of the twentieth century acquired Polish identity. This fact becomes particularly obvious by their inclusion in the 700-page-long postwar culinary compendium Kuchnia Polska (Polish cookery). Published for the first time in 1954, and with twenty-nine editions released by 1989 , this cookbook is said to have been a favorite gift for newlyweds (Kieszek-Wasilewska 2019). Owing to this high penetration ratio, it de facto codified the boundaries of home cooking in communist Poland. Although by no means a dominant group, the collection did not shy away from recipes with clearly labeled foreign connections. For example, the 1962 edition of Kuchnia Polska, which belonged to my grandmother, included twenty such examples (Berger 1962).

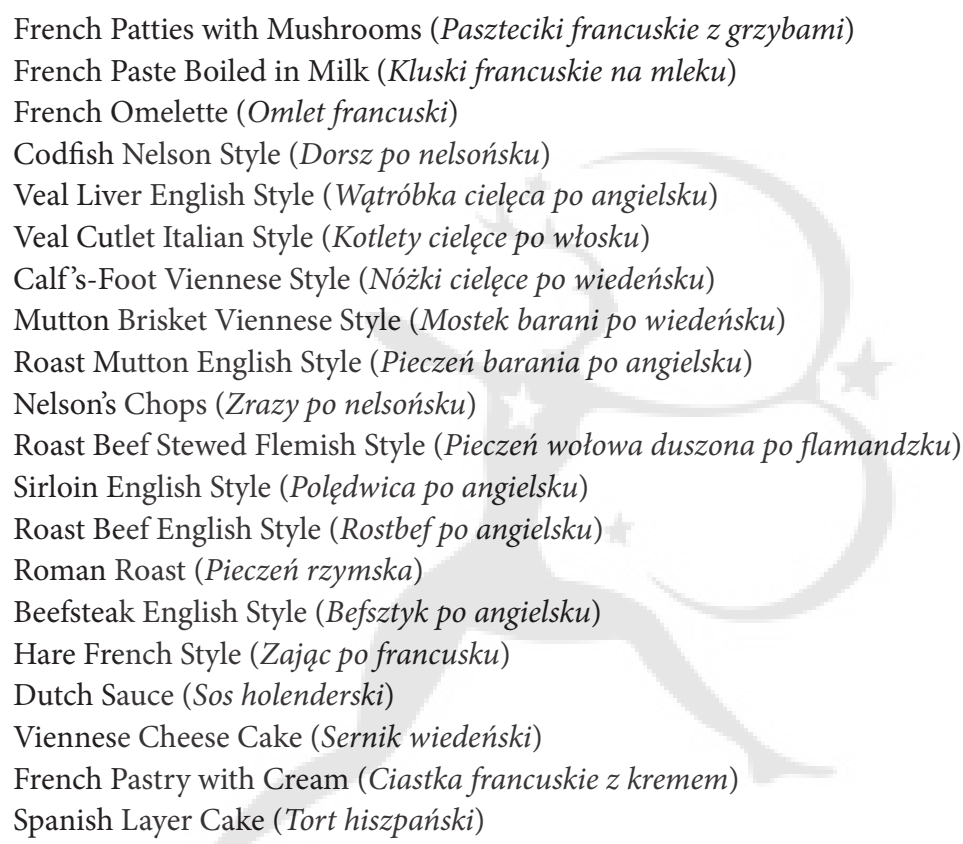

A notable difference with similar recipes that have appeared in Polish household literature since the previous century is that they were now clearly recategorized as "Polish food." It goes without saying that considerable differences can be identified between the original foreign recipes and their Polish versions that ultimately became domesticated. I am skeptical, however, whether analyzing them in order to uncover more information about the Polish taste would be warranted, since modifications in recipes tend to be motivated by practical considerations, such as lack of specific ingredients, equipment, or skills, as well as personal preferences of cookbook writers.

\section{The Hidden Legacy of Food Processing}

Recipes were not the only channel through which foreign influences reached Polish diet since the mid-nineteenth century onward. Industrial food processing slowly but 
surely acquired a foothold in the Polish market as well. One of the earliest instances is the confectionery industry, which began to thrive in the early years of the nineteenth century in the hands of Swiss-Italian immigrants who settled in large cities like Warsaw, Cracow, and Lviv (Herbaczyński 1988, Homola-Skąpska 1996; KozłowskaRyś 2018). The growth of the confectionery business was stimulated by the dropping prices of sugar, which, in turn, was directed related to the spread of the manufacture of sugar from sugar beets. The very first sugar factory set up by German scientist Franz Karl Achard (1753-1821) in Lower Silesia in 1802 soon found imitators, and by the 1850s the industrialization of sugar manufacture was well underway (Przyrembel 1927). Soon, Polish apprentices of foreign confectioners also began to set up their own workshops, but they had to rely on skilled labor from abroad. One of them was Karol Gronert, who in 1845 hired experienced German confectioner Karl Ernst Wedel (1813-1902) to help run his business. Six years later, Wedel opened his own shop, which in time grew to become a full-fledged chocolate emporium with automated factory employing over a thousand people (Herbaczyński 1988: 234-9; Kuta, Matejun, and Miksa 2017: 99). In 1853, the business expended by hiring skilled craftsmen from Berlin and Vienna and importing steam-powered machinery from Paris (History of Our Company 2020). Karl's son Emil Albert Frederick Wedel (1841-1919) took over the control of the business in 1865, and half a century later, under the leadership of his son Jan Joseph Wedel (1874-1960), the brand thrived (Kępa 2018). In 1932, the enterprise became incorporated into E. Wedel Chocolate Factory, and by the end of the decade employed over 1,400 people. A new factory that opened in the city the previous year earlier utilized state-of-the-art machinery for the manufacture of chocolate, along with the automated wrapping equipment (Kuta, Matejun, and Miksa 2017: 99). In 1937, the total volume of production reached 3,500 ton (Lach and Szafran 1987: 73).

Wedel's operations were scaled down after the outbreak of the Second World War, and the consumption of their products restricted primarily to the privileged Germans residing in Poland. After the liberation, the production quickly recovered, and by the late 1940s it had resumed prewar levels. In 1949, the company was nationalized and renamed, and its production portfolio expanded through mergers: in 1960, a merger with one of Wedel's prewar most serious competitors, F. Fuchs and Sons Inc. (F. Fuchs i Synowie S.A.), and six years later with a small factory near Warsaw that specialized in the manufacture of fudge. During the 1970s, the production facilities were thoroughly modernized, relying on cutting-edge machinery imported from West Germany and Italy. Such costly investments were warranted due to an important position of confectionery in Poland's export portfolio, which generated much needed foreign currency. For example, during the 1970s, half of all confectionery exported from Poland was manufactured by the postwar reincarnation of prewar Wedel (Lach and Szafran 1987: 74). Production stagnated during the 1980s, when the economic crisis crippled the supply of cocoa beans and other ingredients (Stępień 1989: 88). In 1991, the Ministry of Ownership Transformation auctioned the enterprise to PepsiCo Foods and Beverages, the highest bidder among the multinational companies that submitted a tender to buy this most famous Polish confectionery producer (Mikołajewska 2014: 74).

While E. Wedel undoubtedly ranked among to top confectionery firms operating in prewar Poland, it is worth pointing out that it acquired the power to shape the 
parameters of the Polish taste only during the communist era. Since its inception in the mid-nineteenth century, Wedel's success had largely relied on foreign know-how and technology, emulating the famous confectioners of Berlin, Paris, and Vienna. This was a prevailing trend among other confectionery manufacturers operating in other parts of Poland as well. In Lviv, they modeled themselves on the Viennese firms of Kohler, Manner, and Heller. In the city of Cracow, three chocolate factories competed with one another: Lachs brothers who operated directly under a license from the Swiss firm Suchard, a branch of the Viennese firm Pischinger (which in 1933 was pushed out of the market by a local copycat illegally using the Pischinger name), and the enterprise of "Chocolate King" Adam Piasecki (1873-1945), run under the watchful eye of a master-chocolatier from Switzerland (Jakubowski 2012: 128-9; Pintowski 1961: 45-6). In 1949, the three were nationalized, based on the Law on Nationalization of Industry (Ustawa o nacjonalizacji przemysłu), passed by the communist government three years earlier. Similarly to the fate of the leading Warsaw firms, Piasecki's chocolate empire was merged with Cracow's Suchard enterprise and the Pischinger copycat, and after 1951 continued under the Wawel brand, named after the Cracow's royal castle (Mazan 2010: 117-18).

The long-standing ties with the foreign chocolate industry were thus abruptly cut off during the second half of the twentieth century. To be sure, foreign machinery continued to be imported. For example, during the 1970s Wedel was furbished with cutting-edge Otto Hansel's evaporators, chocolate-molding equipment by Carle \& Montanari, and Werner \& Pfleider's automatic production lines (Lach and Szafran 1987: 74). However, a relative isolation from foreign inspiration allowed a specific portfolio of prewar confections to develop further in relative isolation, and gradually acquire a distinctively Polish connotation. Limited supply, which required personal connections or long hours of queuing to get hold of the most popular items, only enhanced their cult status. A noteworthy factor that further contributed to the popularity of socialist confectionery was a very limited availability of foreign products, apart from the exorbitantly expensive hard currency PEWEX stores that enjoyed a semi-magical status, especially among children (Burrell 2011: 150; Cwiertka 2011: 1).

The majority of sweets that today are being promoted to foreigners as "typically Polish" - and perceived as such by the population-have socialist roots, but they often rest on prewar foundations of the factories that made them (Kasprzyk-Chevriaux 2016). For example, the list put together in 2014 by Karolina Kowalska for the promotional portal of the Polish Ministry of Foreign Affairs includes two items from Wedel's merchandise: Torcik Wedlowski (Wedel's layer cake), a round block of thin wafers with chocolate filling in-between, and Ptasie mleczko (Bird's Milk), square pieces of marshmallow covered in chocolate (Kowalska 2014). Both were among the new products that the firm launched shortly after the opening of the new factory in 1932, but the former reveals a striking resemblance to "Original Pischinger Torte" claimed by the Pischinger Company to have been invented in the 1880s by Oskar Pischinger, the son of the founder (160 years of tradition: Pischinger then and now 2020).

Foreign food processing businesses moving into the Polish market around the turn of the twentieth century was by no means limited to the chocolate industry. In 1910, ersatz coffee giant Heinrich Franck Söhne Ltd. (est. 1828) set up a factory in 
the town of Skawina, near Cracow. This was merely another step in the aggressive expansion of the firm toward every corner of the Austrian-Hungarian Empire (History 2020). Production in Skawina began the following year, and, by the 1930s, the Polish factory reached a yearly output of 8,200 tons, ranking second among all nine ersatz coffee manufacturers operating across the country (Krupa 2013: 45). Heinrich Franck Söhne's famous brands, such as Enrilo and Karo Franck, were produced here for the Polish consumers. During the early 1940s, the output further increased, since the product was considered by the German occupier as strategic supply for its armed forces (Editorial 1948: 155). In 1949, Skawina factory was nationalized by the newly formed communist government and production portfolio expanded to include noodles, baking powder, and instant soups and Sauces (100 lat tradycji 2020). This strategy could already be observed during the 1920s when the chicory factory set up in 1816 by brothers Bohm in the town of Włocławek branched out to the manufacture of baking powder and other ingredients required for home baking (Fabryka Cykorii we Włocławku BOHM 2020).

These business strategies were undoubtedly inspired by the phenomenal success of the enterprise of August Oetker (1862-1918). The German pharmacist-turnedentrepreneur hit upon the idea of selling baking powder in small sachets with precisely the right quantity of powder for one pound of flour. The powder itself had been discovered half a century earlier by the British chemist Alfred Bird (1811-78), who is also credited with the invention of egg-free custard-another of Dr. Oetker's signature products, alongside prepackaged gelatin and sugar flavored with semisynthetic vanilla extract, known under the brand name Vanillin. Dr. Oetker's talent laid in the improvement of the already-existing products and their marketing, including detailed instructions about how to use them.

The formal founding of the enterprise is January 1, 1891, when Dr. Oetker became the owner of a pharmacy in Bielefeld, but the business began to grow rapidly toward the end of the decade. By 1899, the sale of the baking powder sachets-after 1902 under its own brand name Backin - reached two million sachets, and soon, one after another, factories were built in order to meet the rapidly growing demand (Wirsching, Finger, and Keller 2013: 28-31). Dr. Oetker also began to expand operations beyond the borders of the Kingdom of Prussia, setting up production facilities in Ústí nad Labem, Baden near Vienna, Brno, Maribor, and Budapest. Yet the largest among all the subsidiary enterprises abroad was the factory in the Free City of Danzig (Wirsching, Finger, and Keller 2013: 101). Created in 1920 in accordance with the terms of the Treaty of Versailles, the area consisted of the Baltic port of Danzig (Gdańsk) and nearly 200 surrounding towns and villages. Dr. Oetker began production here in 1922, and a sales branch in Warsaw was opened in 1933 and a representative office in Katowice in 1935 (Wirsching, Finger, and Keller 2013: 34, 89). By 1938, the turnover of the Gdańsk factory reached 27.8 percent of all foreign branches of the firm; the second largest was the Austrian branch with 21.3 percent, followed by Czechoslovakia with 13 percent, Belgium with 11.9 percent, and France 10.3 percent (Wirsching, Finger, and Keller 2013: 101, 424). The promotional sales strategy followed the tried-and-tested model of free-of-charge leaflets and booklets with recipes using Dr. Oetker's products (Leżyński 2020). During wartime, as was the case with ersatz coffee, the output of the Gdańsk 
factory contributed to the provisioning of the German troops. Nationalized during the late 1940s, the factory continued production until 1991, when the Oetker family regained control over the business.

What these fragmented data makes undoubtedly clear is that the novel food processing enterprises that emerged at the end of the nineteenth century in the Kingdom of Prussia and the Austrian-Hungarian Empire moved relatively quickly into the Polish market, and by the 1920s even sparked a handful of local competitors. More importantly, these factories provided a foundation for the food industry to thrive in the communist era. For example, the Swiss concern of Julius Maggi (1846-1912) established a sales office in Poland in 1922, and nine years later began manufacture of precooked soups and stock cubes in the new factory of Poznań. In 1932, its German competitor Knorr also launched production in the same city (Engel 1970: 25). While both firms devoted considerable resources to the promotion of their novel products, the production levels remained relatively low-mere 200 tons of stock cubes in 1937-8 (Kwaśnik 1979: 125). It was only after the war, under the backing of the communist regime, that the business began to flourish. In 1946, Maggi and Knorr were nationalized, and five years later formally merged into one enterprise with a small pasta factory run since 1936 by the Italian Alfredo Germanini (Engel 1970: 25). In 1953, a Polish producer of baking powder and custard powder that had operated in the vicinity was also incorporated into the new venture, which was named Poznan Works of Food Concentrates (Poznańskie Zakłady Koncentratów Spożywczych), since 1968 also known as Amino. Between 1945 and 1969, the volume of production increased sevenfold, by far surpassing the prewar levels of all the individual makers combined. This was largely due to investments in automation and innovative packaging methods, along with the development of new products, such as instant soups and sauces. Per capita consumption of instant soups increased from 0.006 kilogram in 1938 to 4.470 kilogram in 1969 (Engel 1970: 28-9). Another signature product was instant coffee Marago, propagated as the Polish version of Nescafe (Mazan 2010: 186 7 ), and its ersatz version Inka. The latter is not only considered one of the most iconic consumer products of the communist era but also a recipient of the 2016 "Created in Poland Superbrands" award (Inka honoured with Superbrands award 2020). Amino brand continues production under the ownership of Unilever, and the company's logo now permanently includes a phrase "Kuchnia Polska" (Polish cuisine).

Support for the food processing industry by the postwar regime was clearly motivated by ideological factors, mainly the Soviet model of efficient communal canteens combined with women's emancipation through their liberation from the drudgery of the kitchen (Reid 2002). However, the support for food processing was shaped by practical considerations as well. Since food was the country's primary export article, effective preservation and transport of perishables to foreign markets was essential. For example, extensive investments in the refrigeration industry during the 1960s and 1970s constituted a lifeline for the export of Polish fruit, vegetables, and mushrooms (Siemiński 1980).

Another incentive in this respect was reducing dependence on imported ingredients, which were often essential for the manufacture of export articles. For example, by the mid-1960s Poland has become nearly self-sufficient in the production of 
synthetic vanillin - a cheap substitute of vanilla essence-which was an indispensable ingredient for the confectionery industry. Since 1957, vanillin was mass produced by aforementioned enterprise of the Bohm brothers in Włocławek, which had by then been nationalized. The same year, the former Maggi factory in Poznań began producing carotene pigment required in the manufacture of margarine, which had thus far been imported from Denmark (Engel 1970; Stępiński 1962: 334).

In conclusion, similarly to the case of home cooking discussed in the previous section, the communist era was critical in domesticating foreign products that had entered the country during the late nineteenth and the early twentieth centuries. This role was by no means intentional but had twofold consequences. On the one hand, it familiarized the entire population with the products of industrial food processing and the difficulty in acquiring certain items due to shortages only contributed to their cult status. On the other hand, the nationalized enterprises laid the ground for the multinational corporations that flooded the Polish market in the early 1990s by taking over the impoverished state-run enterprises to swiftly establish new production lines. In addition, they could rely on brand recognition of the popular products among the Polish consumers. Today, some of those enterprises may even tap into nostalgia marketing of the communist era products in their promotional activities. For example, a special retro packaging of Calypso brand of ice cream was launched in 2019 on the occasion of celebrating the sixtieth anniversary of the product (Borowski 2019). ${ }^{11}$

\section{Eating Out Foreign Style}

Gastronomy was the least-developed sector within the socialist service economy of the Polish People's Republic, and its growth since the 1990s is one of the most visible sites of the changes that the country underwent in the new political-economic context. According to official statistics, the number of establishments offering gastronomic services in Poland increased nearly tenfold between 1950 and 2015, from 7,281 to 68,342 , with the most rapid growth recorded between 1989 and 2005, when the peak of 92,072 was reached (Głuchowski, Rasińska, and Czarniecka-Skubina 2017: 119). Along with the expansion of the sheer number of gastronomic units, the growth of ethnic sector-meaning the food marketed as representing a specific ethnic identity-was one of the most distinctive features of this transformation (Derek 2017). The market liberalization of the 1990 s prompted a tsunami of foreign culinary trends flooding the Polish gastronomy.

Some of the first and most powerful players that moved into the Polish gastronomic market were McDonald's, Kentucky Fried Chicken, and other American fast-food giants. Today, they remain among the most popular dining establishments in Poland, largely due to their low cost, convenience, and overwhelming presence in shopping malls and in the vicinity of transport hubs (Hebda 2013; Pielak and CzarnieckaSkubina 2016). Their popularity reflects a growing demand, especially among the younger generation, for inexpensive "food-on-the-go" that can be prepared quickly and consumed either at the premises or as a take-out. Precisely the same factors are 
responsible for the spectacular success of "kebab bars" that are now considered the most serious competitors of the American fast-food chains, with franchised business concepts like Bafra Kebab and Berlin Döner Kebab in operation. They are usually staffed by young male immigrants from Muslim countries (Tunisia, Egypt, Algeria, Syria, Iraq, Palestine, and Lebanon), but the food itself is a Turkish-German invention that simply moved east (Möhring 2010; Nowaczek-Walczak 2011).

With a notable exception of Vietnamese food (Wojtasik 2018), all ethnic cuisines that have taken roots in Poland during the last two decades have something in common. They are not a result of an encounter with a specific ethnic group, but rather represent the influx of trends that had already been spreading globally. In other words, Polish cities have since the 1990s gradually joined the "transnational consumer zone" with ethnic dining as its indispensable component, a "global village" disconnected from geographical, climatic, or historical sense of place. Urban citizens of Poland, and the tourists who come to visit the country, can now fully participate in a postmodern culinary taste characterized by "mixed codes, fragmentation, incoherence, disjunction and syncretism" (Scarpato and Daniele 2003: 309).

A survey conducted by Marta Derek in 2013 revealed that the capital city of Warsaw counted 191 gastronomic establishments claiming to serve ethnic food, revealing a growth rate of 45 percent compared to 2001 (Derek 2017: 227-8). Thirty different cuisines were counted, but as the author points out, the most popular ones-Italian and Japanese (read pizza and sushi)—do not reflect at all Poland's geographical location, or a strong presence of Ukrainians in the gastronomic workforce (Derek 2017: 232; Klimek 2016: 68). The findings are confirmed by another study conducted four years later, which concluded that the three dominant cuisines in Warsaw's gastronomy were Polish, Italian, and Japanese (Głuchowski, Rasińska, and Czarniecka-Skubina 2017: 125).

Nationwide, the ranking is slightly different. Italian cuisine remains in the lead, with pizzerias recognized as the most favorite gastronomic establishments, but instead of relatively high-end sushi, American fast-food, kebab, and Chinese/Vietnamese food emerge as favorites (Pielak and Czarniecka-Skubina 2016 11-13; MAKRO Cash and Carry 2016: 13). The same survey, conducted in 2016 by the wholesale operator MAKRO, confirmed that Polish cuisine was still the most preferred eating out option (MAKRO Cash and Carry 2016: 13). An important detail to add is that despite a remarkable growth that Polish gastronomy has experienced since the 1990s, quantitative data confirms that eating out for the bulk of the population remained is site of celebratory meals, reserved for special occasions. For example, according to the data published in 2015, roughly 82-91 percent of respondents consumed their daily meals at home (Domański et al. 2015: 122-4). Another study conducted nationwide in 2011, over a sample of roughly 1,000 responders, indicated that an average Pole visits a gastronomic unit only once a month (Kowalczuk and Czarniecka-Skubina 2015: 76). However, we might surmise that this trend is subject to change in the future, since the younger generation clearly eats out more often: 76.7 percent of 26 to 35 -year-olds and 83.6 percent of 15 to 25 -year-olds declared that they frequent a restaurant, while the ratio was 41 percent for those over sixty-five years of age (Domański 2015: 132). 
When we consider the foreign impact on the twentieth-century Polish gastronomy in the long run, the communist era cannot be left out. This was not only the period of decapitation of prewar gastronomy but was also marked by the influence of the Soviet model of communal feeding. Anastas Mikoyan (1895-1978), the great architect of Soviet-style gastronomy and consumption more broadly, envisaged it as a sciencebased industrialized operation focused on hygiene, nutrition, and efficiency. Mikoyan's vision was inspired by his 1935 trip to the United States, where he picked up and implemented the self-service restaurant (Głuszczenko 2012: 81-3). It is, thus, through the Soviet filter that American gastronomic model has become popularized in Polish People's Republic.

Reorganization of Polish gastronomy based on the Soviet model, which also included ideological integration of workers daily routine through commensality, began the early 1950s with investment in employees' canteens that operated at construction sites and factories, as well as schools and dormitories. By 1954, nearly 10,000 of such gastronomic units were set up (and made up 56 percent of gastronomic establishments in Poland, but half of them did not survive the end of the decade) (Czekalski 2011: 80, 83). Historian Tadeusz Czekalski argues that employees' canteens at no point in Polish history were able to compete with other establishments-most of them state owned-that operated outside the mass-feeding system. For example, during the 1970s, a meager 17 percent of Polish workers made use of employees' canteens (of which only 7 percent consumed their main meal of the day), a rather unimpressive number, especially in comparison to 30 percent in Czechoslovakia and Hungary, 40 percent in the German Democratic Republic, and 75 percent in the Soviet Union (Czekalski 2011: 79-82).

An important new trend of the 1970s, which foreshadowed the ethnic food trend of two decades later, was the appearance of restaurants claiming to be serving the cuisine of comrade nations, appropriately named to underline their identity. The capital city of Warsaw boasted several such enterprises: Trojka, serving Russian cuisine, CristalBudapest Hungarian, Sofia Bulgarian, and Szanghaj Chinese (Brzostek 2010: 245-8). The pride of Szczecin was Bar Kaukaski, which served mutton shashliks Georgian style; Tajik dishes were offered in Gdańsk and Ukrainian cuisine in Cracow restaurant Dniepr (Czekalski 2011: 87). None of those establishments survived the test of time, and none of the cuisines of the countries that once comprised the Soviet Bloc are popular in Poland today. The other trend, which characterized the 1970s, proved much more durable-the rise of private gastronomic businesses. They have grown from 1,465 in 1970 to 4,044 ten years later, and then doubled by 1988 (Kowalczuk and CzarnieckaSkubina 2015: 76). At the fall of the Berlin Wall, private enterprises accounted for the meager 15 percent of the food service sector, but the ratio was soon reversed. By 2013, 98 percent of gastronomic market was privatized (Kowalczuk and Czarniecka-Skubina 2015: 77).

A question remains whether the diversification and capital investment in the Polish gastronomy influenced Polish taste. It is certain that the quality of food served outside the home significantly increased. The same can be said about variety, in particular in relation to regional products. As Dumanowski (2019) explains in his attempt to define Polish cuisine, half a century of communist rule has inflicted vast damage on 
regional culinary variety in Poland due to forced resettlement of population from one region to another, food shortages, the propagation of industrial food processing, and other factors. It is only recently that various initiatives to rescue regional specialties produced on a small scale using artisanal methods are taking place. The establishment, in 2004, of the Polish Chamber of Regional and Local Product (Polska Izba Produktu Regionalnego i Lokalnego) was an important step in increasing the visibility of these initiatives, followed in 2007 by the introduction of the Jakość Tradycja (Quality Tradition) label for artisanal food products, a scheme formally recognized by the Ministry of Agriculture and Rural Development (Ministerstwo Rolnictwa i Rozwoju Wsi) and the European Commission. The financial opportunities offered by the EU's agricultural product quality policies, such as Protected Designation of Origin (PDO), Protected Geographical Indications (PDI), and Traditional Specialty Guaranteed (TSG), are critical for the revitalization of regional food products in Poland. According to the data provided by the Ministry of Agriculture and Rural Development (Ministerstwo Rolnictwa i Rozwoju Wsi), as of May 2020, a total of forty-three products were registered under those three schemes (Produkty zarejestrowane jako Chronione Nazwy Pochodzenia, Chronione Oznaczenia Geograficzne oraz Gwarantowane Tradycyjne Specjalności 2020).

Food has also been recognized as an important asset by the tourist sector and is extensively utilized for place branding (Kruczek and Krauzowicz 2016; Makała 2013; Plebanczyk 2013). As culinary trails, festival, and other culinary events become tourist attractions in their own right, restaurants serving regional cuisine guide many Poles on their journey toward the rediscovery of Polish taste from the precommunist era (Durydiwka 2020: 218-221). ${ }^{12}$ Viewed from this perspective, it is not so much the foreign culinary trends that entered Poland since the 1990s, but rather larger global movements, such as the concerns for sustainability and food safety that often led to a growing of public nostalgia for largely imagined, unidentifiable, authentic past (Caldwell 2002, 2006; Leitch 2003).

\section{Conclusion: Reconnecting with the World}

Sociologist Honorata Jakubowska begins her essay on the transformation that the Polish taste preferences underwent since the 1990s with the section titled "The taste of America" (Smak Ameryki). When describing the circumstances surrounding the opening of American fast-food chains in the Polish cities, she argues that their popularity was driven not by gustatory considerations, but rather by hunger for liberation from the constraints of the communist system. "In 1990s Poland McDonald's did not taste of minced meat, Coke and fries," explains Jakubowska, "it tasted of freedom, open borders, and connection with the rest of the world" (2013: 42, my translation). These sentiments were comparable to the experiences of the citizens of Sofia, Moscow, and Beijing, for whom a serving of Big Mac offered an entry, even for a fleeting moment, to the aura of "American dream" with all its illusive promises of affluence and happiness (Caldwell 2004; Krăsteva-Blagoeva 2001; Yan 2013). 
Today the "reconnecting with the world" project seems completed, at least as far as culinary matters are concerned. Big Mac no longer tastes of freedom, kebab and sushi have lost their exotic connotations, and once-unreachable brand names, like Coca-Cola and Mars, are a familiar presence on the shelves of every supermarket. The political and economic liberalization of the early 1990s, and the influx of multinational corporations onto the Polish market, have created an opportunity for every Pole (if only through advertising) to encounter foreign culinary trends to a degree never experienced before, including most recent ones, such as veganism and food trucks (Głuchowski, Rasińska, and Czarniecka-Skubina 2017: 124-5).

A question worth asking is whether the diversification of food supply brought about by capitalist economy have had any tangible impact on the Polish taste, on Polish culinary identity. And how about the other foreign influences discussed in this chapter? To begin with, it seems obvious that the communist era has contributed to a culinary democratization and was instrumental in sealing of what is now considered the canon of Polish cooking. The recent emphasis on local culinary traditions-also visible in newly published cookbooks-has enriched the classic repertoire. Eating Polish food is becoming increasingly a matter of choice, for some more conscious than for others. The rise of "new Polish cuisine" that combines traditional elements with "lighter" ingredients, often inspired by foreign cuisines, not only is a domain of chefs of upmarket restaurants in Warsaw and Cracow in their dog-eats-dog competition for a mention in Gault \& Millan and Michelin guides, but is also being recognized by ordinary citizens (Jakubowska 2013: 46-7). Combining adjectives, such as "light" (lekka), "fresh" (świeża), and "healthy" (zdrowa), in relation to the term "Polish cuisine" no longer sounds like an oxymoron, which is a harbinger of change looming on the horizon.

In the meantime, Honorata Jakubowska has made a very potent observation that leads me to the conclusion that despite change, some centuries-old taste preferences may be here to stay. In the last section of her aforementioned essay, Jakubowska brings up the American influence that has proved more powerful than the taste of Big Mac: outdoor grilling (2013:48). Within two decades since its introduction in the early 1990s, the custom of barbecuing American style, using a Weber-style kettle grill and charcoal, has turned into a national pastime. Poles grill everywhere-on camp sides, beaches, and lake shores, in the woods and parks, in gardens and allotments, even on balconies, whenever the weather condition allows it. It has become the most widespread form of entertainment for the entire population, regardless the income, since the choice of what to put on the grill depends entirely on the individual budget. Still, among the most popular items are (smoked) sausages and the "traditional" innovation: smoked cheese (oscypek), a regional specialty from the Carpathian Mountains, served with cranberry jelly.

Bonfires are among humanity's oldest customs, but are increasingly regulated due to urbanization, environmental regulations, and fire hazard. I recall with a great deal of nostalgia my childhood holidays in the countryside, which always included bonfires and potatoes baked in the ashes. This is the taste that for me was always intricately connected with the memories of summer holidays. However, for most Poles today the taste of summer is yet again composed of centuries-old smoked foods. 


\section{Notes}

1 Pani Domu, vol. 10 no. 12 (1935).

2 A Polish monetary unit.

3 All editions of the book are available online through the National Library of Poland https://polona.pl/search/?query=365_obiad\%C3\%B3w\&filters=public:1, last accessed on April 25, 2020.

4 Bluszcz, vol. 3 no. 31 (1867).

5 Bluszcz, vol. 5 no. 51 (1869).

6 Bluszcz, vol. 6 no. 24 (1870).

7 Bluszcz, vol. 3 no. 29 (1867).

8 Bluszcz, vol. 8 no. 8 (1872).

9 Dobra Gospodyni, vol. 1 no. 45 (1901).

10 Pani Domu, vol. 12 no. 2, 3, 15-16, 17, 20, 23, 24 (1938).

11 See the website of the producer for the images of the anniversary packaging. https:// www.lodmor.com.pl/

12 The fact that locations without recognizable local dishes/products may resort to fabricating them highlights the potential dangers for the preservation of culinary heritage (Cwiertka 2020). The case in point is Zygmuntówka, an almond cupcake filled with chocolate mousse, cranberry jam, and whipped cream, covered with a crown-shaped meringue. It won the 2009 competition announced by the Warsaw City Hall and the Food Craft Guild to remedy the fact that Warsaw did not have a clearly recognizable dish (Głuchowski, Rasińska, and Czarniecka-Skubina. 2017: 127). The name of the cake alludes to King Sigismund III Vasa (1566-1632), who is responsible for transferring the capital from Cracow to Warsaw in 1596. His statue figures prominently in front of the Royal Castle in the Old Town.

\section{References}

100 Lat Tradycji. 2020. Available online: https://lajkonik.pl/o-firmie/100-lat-tradycji/, last accessed May 3, 2020.

160 Years of Tradition: Pischinger Then and Now (2020). Available online: https://www.pis chinger.at/en/about-pischinger/, last accessed May 3, 2020.

A Foreigner's Guide to Polish Cuisine (2014). Available online: https://culture.pl/en/article/ a-foreigners-guide-to-polish-cuisine, last accessed June 3, 2020.

Anderson, B. R. (1991), Imagined Communities: Reflections on the Origin and Spread of Nationalism, London: Verso.

Berger, S., ed. (1962 [1954]), Kuchnia Polska, Warszawa: Państwowe Wydawnictwo Ekonomiczne.

Borowski, R. (2019), Lody Calypso maja już 60 lat. Available online: https://biznes.trojm iasto.pl/Lody-Calypso-maja-juz-60-lat-n135081.html, last accessed June 3, 2020.

Brzostek, B. (2010), PRL na widelcu, Warszawa: Baobab.

Burrell, K. (2011), “The Enchantment of Western Things: Children's Material Encounters in Late Socialist Poland," Transactions of the Institute of British Geographers 36(1): 143-56.

Caldwell, M. L. (2002), “The Taste of Nationalism: Food Politics in Postsocialist Moscow," Ethnos 67(3): 295-319. 
Caldwell, M. L. (2004), "Domesticating the French Fry: McDonald's and Consumerism in Moscow," Journal of Consumer Culture 4(1): 5-26.

Caldwell, M. L. (2006), "Tasting the Worlds of Yesterday and Today: Culinary Tourism and Nostalgia in Post-Soviet Russia," in R. Welk (ed.), Fast Food/Slow Food: Cultural Economy of the Global Food System, pp. 97-113, New York: Rowman \& Littlefield.

Ćwierczakiewiczowa, L. (1985 [1860]), 365 Obiadów, Kraków: Krajowa Agencja Wydawnicza.

Cwiertka, K. J. (2006), Modern Japanese Cuisine: Food, Power and National Identity, London: Reaktion Books.

Cwiertka, K. J. (2011), The Wisdom of the Ordinary: A Prospect for Modern Japan Studies, Inaugural Lecture, Leiden University. Available online: https://openaccess.leidenuniv.nl /handle/1887/19586, last accessed June 3, 2020.

Cwiertka, K. J. (2020), Branding Japanese Food: From Meibutsu to Washoku, Honolulu: Hawai'i University Press.

Czaplicki, W. and J. Długosz (1976), Życie Codzienne Magnaterii Polskiej w XVII Wieku, Warszawa: Państwowy Instytut Wydawniczy.

Czekalski, T. (2011), "Przedsiębiorstwa Żywienia Zbiorowego w Realiach PRL: Model Żywienia Zbiorowego w Warunkach Przyspieszonej Modernizacji i jego Realizacja," Annales Universitatis Paedagogicae Cracoviensis: Studia Politologica 5: 78-90.

Czerny, Z. (1954), Ksiażka Kucharska, Warszawa: Polskie Wydawnictwo Gospodarcze.

Czerny, Z. and M. Strasburger (1948), Żywienie Rodziny, Warszawa: Czytelnik.

Dembińska, M. (1999), Food and Drink in Medieval Poland: Rediscovering a Cuisine of the Past, trans. M. Thomas, Philadelphia: University of Pennsylvania Press.

Derek, M. (2017), "Multi-ethnic Food in the Mono-ethnic City: Tourism, Gastronomy and Identity in Central Warsaw," in D. Hall (ed.), Tourism and Geopolitics: Issues and Concepts from Central and Eastern Europe, pp. 223-35, Wallingford: CAB International.

Domański, H., Z. Karpiński, D. Przybysz, and J. Straczuk (2015), Wzory Jedzenia a Struktura Społeczna, Warszawa: Wydawnictwo Naukowe Scholar.

Dumanowski, J. (2019), Co to jest kuchnia polska? Unpublished manuscript.

Durydiwka, M. (2020), "Eating Establishments in Smaller Cities and Towns in Poland (on Selected Examples)," in A. Kowalczyk and M. Derek (eds.), Gastronomy and Urban Space: Changes and Challenges in Geographical Perspective, pp. 209-23, Cham: Springer.

Editorial (1948), “Monografie Fabryk i Przedsiębiorstw: Fabryka Środków Kawowych H. Franck i Synowie w Skawinie k/Krakowa," Przemyst Spożywczy 2 (5-6): 155-7.

Eliot, S. and J. Rose, eds. (2007), A Companion to the History of the Book, Oxford: Blackwell.

Engel, W. (1970), “Poznańskie Zakłady Koncentratów Spożywczych 'Amino' w latach 1929-1969 (szkic monograficzny)," Kronika Miasta Poznania 38(2): 25-38.

Fabryka Cykorii we Włocławku BOHM (2020). Available online: https://historiawloclawka .pl/historia-wloclawskich-zakladow/25-fabryka-cykorii-we-wloclawku-bohm, last accessed June 3, 2020.

Głuchowski, A., E. Rasińska, and E. Czarniecka-Skubina (2017), "Rynek Usług Gastronomicznych w Polsce na Przykładzie Warszawy," Handel Wewnętrzny 4(369): $118-33$.

Głuszczenko, I. (2012), Sowiety od Kuchni: Mikojan i Radziecka Gastronomia, trans. M. Przybylski, Warszawa: Wydawnictwo Krytyki Politycznej. 
Hebda, A. (2013), "Fast Food Nie Tylko Na Szybko," in A. Jawor (ed.), Paradoksy Ponowoczesności. O Starciach Płci, Religii, Tożsamości, Norm i Kultur, pp. 149-75, Warszawa: Wydawnictwo Naukowe Scholar.

Herbaczyński, W. (1988), W Dawnych Cukierniach i Kawiarniach Warszawskich, Warszawa: Państwowy Instytut Wydawniczy.

History (2020). Available online: https://www.franck.eu/en/history/, last accessed June 3, 2020.

History of Our Company (2020). Available online: http://www.wedel.com/\#history, last accessed April 20, 2020.

Homola-Skąpska, I. (1996), "Krakowskie Cukiernie i Kawiarnie w XIX Wieku," Annales Universitatis Mariae Curie-Skłodowska 6(5): 43-61.

Inka Honoured with Superbrands Award (2020). Available online: https://www.grana.pl/en/ inka-honoured-with-superbrands-award/, last accessed August 7, 2020.

Jakubowska, H. (2013), "Polskie Smaki/ Smaki w Polsce," Czas Kultury 5: 40-9.

Jakubowski, K. (2012), Kawa i Ciasto o Każdej Porze. Historia Krakowskich Kawiarni i Cukierni, Warszawa: Agora.

Kalkowski, J. (1985), “O autorce '365 obiadów,” in L. Ćwierczakiewiczowa, 365 Obiadów, Kraków: Krajowa Agencja Wydawnicza, pp. 5-16.

Kasprzyk-Chevriaux, M. (2016), Polish Food 101: Iconic Sweets. Available online: https://culture.pl/en/work/polish-food-101-iconic-sweets, last accessed June 12, 2020.

Kępa, M. (2018), The Bitter-Sweet Story of Wedel, Poland's Famous Chocolatier. Available online: https://znakitowarowe-blog.pl/ptasie-mleczko/, last accessed May 12, 2020.

Kieszek-Wasilewska, I. (2019), Kuchnia Polska. Available online: https://kukbuk.pl/artykul y/kuchnia-polska/, last accessed March 25, 2020.

Klimek, D. (2016), “Znaczenie Migracji Zarobkowej z Ukrainy dla Gospodarki, Przedsiębiorców i Rynku Pracy w Polsce," Zeszyty Naukowe Uczelni Vistula 47(2): 60-74.

Kowalczuk, I. and E. Czarniecka-Skubina (2015), "Eating Out in Poland: History, Status, Perspectives and Trends," Scientific Journal of University of Szczecin Service Management 16: 75-83.

Kowalska, K. (2014), Sweets Serve as Exquisite Souvenirs from Poland. Available online: https://poland.pl/tourism/cuisine/polish-sweets/, last accessed March 25, 2020.

Kozłowska-Ryś, A. (2018), Lwów na Słodko i . . Pótwytrawnie, Poznań: Liberum.

Krăsteva-Blagoeva, E. (2001), “The Bulgarians and McDonald's: Some Anthropological Aspects," Ethnologia Balkanica 5: 207-17.

Kruczek, Z. and M. Krauzowicz (2016), "Turystyka Kulinarna na Podhalu," Zeszyty Naukowe Turystyka i Rekreacja 18(2): 17-34.

Krupa, M. (2013), "Przemiany Architektoniczne Skawiny w 2 Połowie XIX i na Początku XX Wieku. Cz. I. Zakłady Przemysłowe,” Wiadomości Konserwatorskie 35: 41-6.

Kuta, K., M. Matejun, and P. Miksa (2017), “Długowieczność Firm Rodzinnych,” Przegląd Nauk Ekonomicznych 26: 91-102.

Kuti, K. (2003), "Poland," in S. H. Katz (ed.), Encyclopedia of Food and Culture, vol. 1, pp. 349-50, New York: Charles Scribner's Sons.

Kwaśnik, E. (1979), "Przemysł Koncentratów Spożywczych w Polsce," Przemysł Spożywczy 33(5-6): 125-7.

Lach, J. and G. Szafran (1987), "Wczoraj i Dziś Zakładów Przemysłu Cukierniczego w Warszawie," Przemyst Spożywczy 41(3): 73-5.

Leitch, A. (2003), "Slow Food and the Politics of Pork Fat: Italian Food and European Identity," Ethnos 68(4): 437-62. 
Leżyński, P. (2020), Fabryka Środków Spożywczych Dr. Oetker. Available online: http://www.dawnaoliwa.pl/opisy/firmy/oetker.html, last accessed May 15, 2020.

Makała, H., ed. (2013), Kulturowe Uwarunkowania Żywienia w Turystyce, Warszawa: Wyższa Szkoła Turystyki i Języków Obcych.

MAKRO Cash \& Carry (2016), Polska na Talerzu. Available online: https://mediamakro.pl /pr/313540/jak-ksztaltuja-sie-preferencje-kulinarne-polakow-raport-polska-na-talerzu -2016, last accessed June 11, 2020.

Mazan, L. (2010), Kraków na Słodko, Kraków: Anabasis.

Meller, B. (1994a), “Obce Wpływy w Kuchni Polskiej," in J. Łoziński and M. Łozińska (eds.), Wokół Stołu i Kuchni, pp. 33-55, Warszawa: Wydawnictwo Tenten.

Meller, B. (1994b), "Książki Kucharskie w XIX Wieku," in J. Łoziński and M. Łozińska (eds.), Wokół Stołu i Kuchni, pp. 81-9, Warszawa: Wydawnictwo Tenten.

Michalik, M. and M. Łebkowski (1996), Mała Encyklopedia Sztuki Kulinarnej, Warszawa: Wydawnictwo Tenten.

Mikołajewska, K. (2014), "Alienation and Rush towards Change: Introducing Capitalism to a State-owned Polish Enterprise," Oral History 42(2): 69-80.

Möhring, M. (2010), "Döner Kebab and West German Consumer (Multi-) Cultures," in U. Lindner, M. Möhring, M. Stein, and S. Stroh (eds.), Hybrid Cultures Nervous States: Britain and Germany in a (Post)Colonial World, pp. 151-66, Amsterdam, New York: Rodopi.

Norkowska, M. (1903), Najnowsza Kuchnia Wytworna i Gospodarska, Warszawa: Gebethner i Wolf.

Nowaczek-Walczak, M. (2011), "The World of Kebab: Arabs and Gastronomy in Warsaw," in K. Górak-Sosnowska (ed.), Muslims in Poland and Eastern Europe: Widening the European Discourse on Islam, pp. 108-25, Warszawa: Faculty of Oriental Studies, Warsaw University.

Ochorowicz-Monatowa, M. (1995 [1912]), Uniwersalna Ksiażka Kucharska, Warszawa: Wydawnictwo Graf-Punkt.

Palmer, C. (1998), "From Theory to Practice: Experiencing the Nation in Everyday Life," Journal of Material Culture 3(2): 175-99.

Pielak, M. and E. Czarniecka-Skubina (2016), "Kulinarne Preferencje Polskich Konsumentów w Zakresie Kuchni Etnicznych," Zeszyty Naukowe Turystyka i Rekreacja 18(2): 5-15.

Pintowski, F. (1961), “Uwagi o Rozwoju Polskiego Przemysłu Cukierniczego," Przemyst Spożywczy 15(12): 43-6.

Plebańczyk, K. (2013), “Turystyka Kulinarna w Kontekście Zrównoważonego Rozwoju w Kulturze - Perspektywy dla Polski," Turystyka Kulturowa 10(10): 23-38.

Produkty Zarejestrowane jako Chronione Nazwy Pochodzenia, Chronione Oznaczenia Geograficzne oraz Gwarantowane Tradycyjne Specjalności (2020), Ministerstwo Rolnictwa i Rozoju Wsi. Available online: https://www.gov.pl/web/rolnictwo/produkty -zarejestrowane-jako-chronione-nazwy-pochodzenia-chronione-oznaczenia-geografic zne-oraz-gwarantowane-tradycyjne-specjalnosci, last accessed June 10, 2020.

Przyrembel, Z. (1927), Historja Cukrownictwa w Polsce, T. 1, Warszawa: Published by the author.

Reid, S. E. (2002), "Cold War in the Kitchen: Gender and the De-Stalinization of Consumer Taste in the SovietUnion under Khrushchev," Slavic Review 61(2): 211-52.

Scarpato, R. and R. Daniele (2003), "New Global Cuisine: Tourism, Authenticity and Sense of Place in Postmodern Gastronomy," in C. M. Hall, L. Sharples, R. Mitchell, N. Macionis, and B, Cambourne (eds.), Food Tourism Around the World: Development, Managment, Markets, pp. 296-313, Oxford: Butterworth-Heinemann. 
Siemiński, J. (1980), "Pięćdziesięciolecie Polskiego Chłodnictwa," Przemysł Spożywczy 34(9): 364-6.

Stępień, A. (1989), “Wedel'- Historia i Perspektywa Rozwoju," Przemysł Spożywczy 18(4): 87-9.

Stępiński, M. (1962), "Przemysł Spożywczy Rozwija Produkcję Antyimportową," Przemyst Spożywczy 16(6): 333-6.

Szymanderska, H. (2006), Encyklopedia Polskiej Sztuki Kulinarnej: 2400 Przepisów, Warszawa: Wydawnictwo REA.

Wirsching, A., J. Finger, and S. Keller (2013), Dr. Oetker und der Nationalsozialismus. Geschichte eines Familienunternehmens 1933-1945, München: Beck.

Wojtasik, M. (2018), "Aleja Wietnamskich Barów na Bazarze pod Stadionem

Dziesięciolecia jako Miejsce Spotkań Kultur i Klas," Societas/Communitas 25(1b): 105-24.

Yan, Y. (2013), "Of Hamburger and Social Space: Consuming McDonald's in Beijing," in C. Counihan and P. Van Esterik (eds.), Food and Culture: A Reader, Third edition, pp. 449-71, New York: Routledge.

Zamoyski, A. (1987), The Polish Way: A Thousand-year History of the Poles and Their Culture, London: John Murray. 